\title{
Influence of Plant Growth Regulators on Rooting of Stem Cuttings in Jamun (Syzygium cumini L. Skeels)
}

\author{
B. M. Bhairavi ${ }^{*}$, D. P. Prakasha ${ }^{2}$, H. Kulapathi ${ }^{3}$, N. Anand ${ }^{4}$, \\ G. R. Sanjeev Raddi $^{5}$ and S. G. Gollagi ${ }^{6}$ \\ ${ }^{1}$ College of Horticulture, UHS Bagalkot-587 104, India \\ ${ }^{2}$ Department of Fruit Sciences, College of Horticulture, Munirabad-583 233, \\ Koppal (Tq and Dist), Karnataka State, India \\ ${ }^{3}$ Department of Fruit Sciences, Bagalkot-587 104, India \\ ${ }^{4}$ Department of Fruit Sciences and Farm superintendent, College of Horticulture, UHS \\ Bagalkot-587 104, India \\ ${ }^{5}$ Department of Agronomy, College of Horticulture, UHS Bagalkot-587 104, India \\ ${ }^{6}$ Department of Plant Physiology, College of Horticulture, UHS Bagalkot-587 104, India \\ *Corresponding author
}

\begin{abstract}
A B S T R A C T
Keywords

Jamun, rooting, stem cutting, PGRs, vegetative propagation, IBA

\section{Article Info}

Accepted:

04 August 2019 Available Online:

10 September 2019

Vegetative propagation of Jamun (Syzygium cumini L. Skeels) through cutting is the most convenient and the cheapest method to obtain true to type plants in considerably lesser time. In the present study, effect of various concentration of PGR's on the rooting ability of different types of stem cuttings of jamun was assessed at College of Horticulture, University of Horticultural sciences, Navanagar, Bagalkot (Karnataka) India. The experiment was laid out in Factorial Completely Randomized Design. There was significant differences among treatments in various shoot and root parameters recorded. The hardwood cuttings and rootex (commercial formulation) were significantly best with respect to most of the shoot and root parameters. In the interaction of treatments, number of days taken for sprout initiation was found early in $\mathrm{T}_{21}$ (Hardwood cutting and Rootex, 8.65days), the highest number of sprouts (12.05), number of leaves per cutting (9.15) and length of shoots $(8.64 \mathrm{~cm})$ at 30, 60 and 90 DAP, sprouting percentage (29.90), fresh weight of cuttings $(21.47 \mathrm{~g})$, dry weight of cuttings $(14.25 \mathrm{~g})$, number of primary and secondary roots $(57.60)$, length of longest root $(16.85 \mathrm{~cm})$, and rooting percentage $(35.40)$ at 90 DAP was more in interaction $\mathrm{T}_{21}$ (Hard wood cutting and rootex). Overall, $\mathrm{T}_{21}$ having interaction of hard wood cutting and rootex was shown superior results as compared to other treatments.
\end{abstract}

\section{Introduction}

The Jamun (Syzygium cumini L. Skeels) commonly known as Indian blackberry, Java plum, Jambu, black plum and Jambul belongs to family Myrtaceae are important evergreen beautiful tree, native to India. S. cumini is an emerging fruit crop of the twenty-first century. The fruit contains various pharmacological active phytochemicals such as alkaloids, fatty 
acids, steroids and tannins. The fruit is also known as diabetic-fighter because of its hypoglycemic properties. The dried alcoholic extract of jamun seeds has the potential to reduce blood sugar and glycosuria. The plants raised by seed takes long period to flower and bear fruits. Seed propagated plant bears fruits of variable size and quality. The percentage of germination and seed longevity of jamun is eight per cent and three week respectively. (Roberts, 1983). Therefore vegetative propagation is utmost desirable to propagate true to type plants. Propagation by cuttings is the most convenient and cheap method of obtaining a fully developed stronger tree in considerably less time. Auxin has varying degree of effectiveness in promoting adventitious roots in stem cuttings of many species. It has been suggested that auxin promotes growth of avena coleoptile by induction of hydrogen ion secretion and cell wall acidification (Cleland, 1973).

Furthermore, Tripathi and Shukla (2004) reported that the maximum rooting percentage in pomegranate cutting was recorded under 1000 ppm PHB + 5000 ppm IBA and the maximum number of root per cutting was also recorded under $1000 \mathrm{ppm} \mathrm{PHB}+5000 \mathrm{ppm}$ IBA. The research work on rooting of jamun cuttings is very limited. Keeping these points in view the present study was conducted to study the influence of PGRs on success of rooting ability of different types of stem cuttings of jamun.

\section{Materials and Methods}

The experiment was conducted at College of horticulture, University of Horticultural sciences, Navanagar, Bagalkot (Karnataka) India. The experiment was laid out in Factorial completely randomized design. There were seven treatments of different PGR combination. Each treatment was replicated twice.

\section{Preparation of cuttings}

Jamun (Syzygium cumini L. Skeels) stem cuttings were taken from well-developed disease free mother plants.

The cuttings were $15 \mathrm{~cm}$ long, containing about 4 to 5 buds. In the present study three types of stem cuttings were taken, which are as follows:

Hard-wood cuttings: The branches of pencil thickness from the past season growth having an age of seven to nine months were selected from the mother plant. All the leaves were removed by using secateurs. The length of the cuttings were retained about 15 to $20 \mathrm{~cm}$.

Semi-hardwood cuttings: The branches of pencil thickness from the past season growth having an age of seven to nine months were selected.

The length of the stem cuttings were $15 \mathrm{~cm}$. few top leaves were retained in the cuttings.

Shoot tip cuttings: These are the fast growing soft tips of stems, usually taken from four to five months old shoots having a length of 15 $\mathrm{cm}$, including the terminal bud.

A slanting cut was given at the upper side and a flat cut was given at the lower end of the cutting.

\section{Preparation of growth regulator}

The cuttings was treated with growth regulators by quick dip method and for this a required amount of growth regulator was weighed and dissolved in $0.2 \mathrm{~N} \mathrm{NaOH}$ and then the volume was made up to 1 litre using distilled water and the cutting was dipped in solution for 2 minutes (Ayesha and Thippesha, 2018) and planted in portrays containing cocopeat as media. 


\section{Selection of treatments}

Factor A (Seven growth regulators levels)

$\mathrm{G}_{1} \mathrm{IBA} 2,000 \mathrm{ppm}, \mathrm{G}_{2}$ IBA 3,000 ppm, $\mathrm{G}_{3}$ IBA 4,000 ppm, G4 IBA 2,000+ PHB 750 ppm G IBA 3,000 + PHB (P- Hydroxy benzoic Acid) $750 \mathrm{ppm}$, G6 IBA 4,000+ PHB $750 \mathrm{ppm}$ and G7 Rootex (commercial formulation for rooting) and Factor $\mathrm{B}$ (Three types of cuttings)- $\mathrm{C}_{1}$ Hardwood cuttings, $\mathrm{C}_{2}$ Semi Hardwood cuttings and $\mathrm{C}_{3}$ Shoot tips Cuttings.

\section{Induction of treatments}

Factor A and Factor B were combined and 21 treatments obtained are as follows; $\mathrm{T}_{1}-\mathrm{C}_{1}$ Hardwood cuttings $+\mathrm{G}_{1}$ IBA $2,000 \mathrm{ppm}, \mathrm{T}_{2}$ $\mathrm{C}_{2}$ Semi-hardwood cutting $+\mathrm{G}_{1}$ IBA 2,000 ppm, $T_{3-} C_{3}$ Shoot-tip cutting+ $\mathrm{G}_{1}$ IBA 2,000 ppm, $\mathrm{T}_{4-} \mathrm{C}_{1}$ Hardwood cuttings $+\mathrm{G}_{2}$ IBA 3,000 ppm, $\mathrm{T}_{5}-\mathrm{C}_{2}$ Semi-hardwood cutting + $\mathrm{G}_{2}$ IBA 3,000 ppm, $\mathrm{T}_{6-} \mathrm{C}_{3}$ Shoot-tip cutting + $\mathrm{G}_{2}$ IBA 3,000 ppm, $\mathrm{T}_{7} . \mathrm{C}_{1}$ Hardwood cuttings $+\mathrm{G}_{3}$ IBA 4,000 ppm, $\mathrm{T}_{8-} \mathrm{C}_{2}$ Semi-hardwood cutting $+\mathrm{G}_{3}$ IBA 4,000 ppm, $\mathrm{T}_{9-} \mathrm{C}_{3}$ Shoot-tip cutting $+\mathrm{G}_{3}$ IBA 4,000 ppm, $\mathrm{T}_{10-} \mathrm{C}_{1}$ Hardwood cuttings $+\mathrm{G}_{4}$ IBA $2,000+$ PHB $750 \mathrm{ppm}, \mathrm{T}_{11}$ $\mathrm{C}_{2}$ Semi-hardwood cutting $+\mathrm{G}_{4}$ IBA 2,000+ PHB $750 \mathrm{ppm}, \mathrm{T}_{12-} \mathrm{C}_{3}$ Shoot-tip cutting $+\mathrm{G}_{4}$ IBA 2,000 + PHB $750 \mathrm{ppm}, \mathrm{T}_{13}-\mathrm{C}_{1}$ Hardwood cuttings $+\mathrm{G}_{5}$ IBA 3,000 + PHB $750 \mathrm{ppm}, \mathrm{T}_{14}$ $\mathrm{C}_{2}$ Semi-hardwood cutting $+\mathrm{G}_{5}$ IBA 3,000+ PHB $750 \mathrm{ppm}, \mathrm{T}_{15-} \mathrm{C}_{3}$ Shoot-tip cutting $+\mathrm{G}_{5}$ IBA 3,000 + PHB $750 \mathrm{ppm}, \mathrm{T}_{16-} \mathrm{C}_{1}$ Hardwood cuttings + G6 IBA 4,000 + PHB $750 \mathrm{ppm}, \mathrm{T}_{17}$ $\mathrm{C}_{2}$ Semi-hardwood cutting + G6 IBA 4,000 + PHB $750 \mathrm{ppm}, \mathrm{T}_{18-} \mathrm{C}_{3}$ Shoot-tip cutting + G6 IBA 4,000 + PHB 750 ppm, $\mathrm{T}_{19}$ - $\mathrm{C}_{1}$ Hardwood cuttings + G7 Rootex, $\mathrm{T}_{20-} \mathrm{C}_{2}$ Semi-hardwood cutting + G7 Rootex and $\mathrm{T}_{21}-\mathrm{C}_{3}$ Shoot-tip cutting + G7 Rootex.

\section{Observations}

The observations taken were days taken for sprout initiation, sprouting percentage, number of sprouts, number of leaves and length of shoots at 30, 60 and 90 days after planting and fresh weight of cuttings, dry weight of cuttings, number of primary and secondary roots, length of longest root, and rooting percentage at 90 Days after planting.

\section{Dry weight (g)}

After the fresh weight was taken, the jamun cuttings was taken in the butter paper bags. Tagging was done to individual paper bags according to the treatments to avoid mechanical mixture. After that, the tagged paper bags were put in the hot air oven at $100^{\circ} \mathrm{F}$ for few days until the mass gets constant.

\section{Statistical analysis}

The data recorded for all the parameters was statistically analysed (ANOVA) by following the completely randomized design (CRD) at 5\% level of significance. The analysis has been done in Web Agri-Stat Package (WASP 2.0) developed by ICAR Research Complex, Goa.

\section{Results and Discussion}

\section{Effect on days taken for sprout initiation}

The numbers of days taken for sprout initiation in jamun stem cuttings was significantly influenced by various levels growth regulators and type of cuttings and their interactions. Shoot-tip cuttings (11.46 days) were early than others and rootex (11.20 days) was the best in early sprout initiation compared to other propagation conditions (Table 1). In the interaction, the minimum number of days of 8.65 was recorded for sprouting initiation in $\mathrm{T}_{21}\left(\mathrm{C}_{3}\right.$ Shoot-tip cutting + G7 Rootex), which was on par with $\mathrm{T}_{9}\left(\mathrm{C}_{3}\right.$ Shoot-tip cutting ${ }_{+} \mathrm{G}_{3}$ IBA 4,000 ppm) and $\mathrm{T}_{18}$ $\left(\mathrm{C}_{3}\right.$ Shoot-tip cutting + G6 IBA 4,000 + PHB 
$750 \mathrm{ppm}$ ) with 9.50 and 9.70 days respectively (Table 3). The maximum number of days (15.50) taken for sprout initiation was recorded in treatment $\mathrm{T}_{1}-\mathrm{C}_{2}$ - Semi-hardwood cutting $+\mathrm{G}_{1}$ IBA $2,000 \mathrm{ppm}$. Earliest sprouting of cutting may be due to prevention of down-word translocation of carbohydrate and accumulation of higher level of endogenous and exogenous auxins and also due to the exogenous application of auxin which hydrolysis starch into sugars. This is needed to a greater extent for the production of new cells and for increased respiratory activity in the regeneration tissue at the time of initiation of new root primordial (Bhattacharjee and Thimmappa, 1993). Similar results were also reported by Hussain et al., (2016) in sweet lime and Kumar et al., (2004) in sweet lime.

\section{Effect on number of sprouts per cutting}

In the present study growth regulators and type of cuttings and their combinations exhibited significant effect on average number of sprouts per cutting. Highest number of sprouts was recorded in hardwood cuttings $(9.79,8.29$ and 5.11) and rootex $(9.49,8.49$ and 5.90) as compared to other type of cuttings and PGR's at 30, 60, and 90 days after planting, respectively (Table 1). In the interaction, the maximum number of sprouts per cutting $(12.05,10.05$ and 6.10) was recorded in $\mathrm{T}_{19}-\mathrm{C}_{1}$ - Hardwood cuttings $+\mathrm{G} 7$ Rootex. Whereas, the minimum number of sprouts per cutting (5.91- $\mathrm{T}_{3}-\mathrm{C}_{3}$ Shoot-tip cutting $+\mathrm{G}_{1}$ IBA 2,000 ppm, 5.41- $\mathrm{T}_{3}-\mathrm{C}_{3}$ Shoot-tip cutting $+\mathrm{G}_{1}$ IBA $2,000 \mathrm{ppm}$ and 3.90- $\mathrm{T}_{15}-\mathrm{C}_{3}$ Shoot-tip cutting $+\mathrm{G}_{5}$ IBA 3,000 + PHB $750 \mathrm{ppm}$ ) was recorded at 30,60 and 90 days after planting, respectively (Table 3 ). Increase in sprouting percentage in hardwood cuttings may be due to better utilization of stored carbohydrate, nitrogen and other factor with the aid of growth regulator. Rootex treated cuttings had more sprouts per cutting as it was adhered with the cut end of the cuttings for a prolonged period. Similar results were also reported by Siddiqui and Hussain (2007) in Ficus and Tripathi and Shukla (2004) in pomegranate.

\section{Effect on percent sprouted cuttings}

In the present study growth regulators and type of cuttings and their combinations exhibited significant effect on sprout percentage. Highest percentage of sprouting was recorded in the hardwood cuttings (12.68 $\%$ ) compared to other type of cuttings and rootex $(16.19 \%)$ was best condition to record highest sprouting compared to other conditions (Table 1). In the interaction, the highest sprouting percentage was recorded in treatment $\mathrm{T}_{19}\left(\mathrm{C}_{1}\right.$ Hardwood cuttings $+\mathrm{G} 7$ Rootex) with 29.90 per cent whereas lowest sprouting percentage was observed in treatment $\mathrm{T}_{12}\left(\mathrm{C}_{3}\right.$ Shoot-tip cutting $+\mathrm{G}_{4}$ IBA $2,000+$ PHB $750 \mathrm{ppm}$ ) with 2.31 per cent (Table 3). Increase in sprouting percentage in hardwood cuttings may be due to better utilization of stored carbohydrate, nitrogen and other factor with the aid of growth regulator. Similar results were also reported by Bastos et al., (2006) in litchi, Siddiqui and Hussain (2007) in Ficus and Hussain et al., (2016) in sweet lime.

\section{Effect on number of leaves per cutting}

In the present study growth regulators and type of cuttings and their combinations exhibited significant effect on average number of leaves per cutting. Highest number of leaves was recorded in hardwood cuttings (4.76, 6.73 and 7.72) and rootex (5.29, 7.46 and 8.19) as compared to other type of cuttings and PGR's at 30,60, and 90 days after planting, respectively (Table 1). In the interaction, the maximum number of leaves per cutting (5.68, 8.15 and 9.15) was recorded in $\mathrm{T}_{19}\left(\mathrm{C}_{1}\right.$ Hardwood cuttings $+\mathrm{G} 7$ Rootex $)$ as 
presented in (Table.3). Whereas, the minimum number of leaves per cutting of $\left(3.05-\mathrm{T}_{15}-\mathrm{C}_{3}\right.$ Shoot-tip cutting $+\mathrm{G}_{5}$ IBA 3,000 + PHB 750 ppm, 4.12- $\mathrm{T}_{12-} \mathrm{C}_{3}$ Shoot-tip cutting $+\mathrm{G}_{4}$ IBA $2,000+$ PHB $750 \mathrm{ppm}$ and 5.12- $\mathrm{T}_{12}-\mathrm{C}_{3}$ Shoot-tip cutting $+\mathrm{G}_{4}$ IBA $2,000+$ PHB 750 ppm) was recorded at 30, 60 and 90 days after planting, respectively (Table 1). Increase in number of leaves might be due to effect of exogenous and endogenous auxin. Rootex treated cuttings had more leaves per cutting as it was adhered with the cut end of the cuttings for a prolonged period. Similar results were also reported by Gurjar and Patel (2006) in pomegranate, Singh et al., (2016) in phalsa and Hussain et al., (2016) in sweet lime.

\section{Effect on shoot length}

In the present study growth regulators and type of cuttings and their combinations exhibited significant effect on average shoot length. Highest shoot length was recorded in hardwood cuttings $(4.66,5.93$ and $5.11 \mathrm{~cm})$ and rootex $(6.25,7.62$ and $7.93 \mathrm{~cm})$ as compared to other type of cuttings and PGR's at 30, 60, and 90 days after planting, respectively (Table 2 ). In the interaction, the maximum shoot length $\left(6.45 \mathrm{~cm}-\mathrm{T}_{20}-\mathrm{C}_{2} \mathrm{Semi}-\right.$ hardwood cutting + G7 Rootex, $8.15 \mathrm{~cm}-\mathrm{T}_{19}-$ $\mathrm{C}_{1}$ Hardwood cuttings $+\mathrm{G} 7$ Rootex and $8.54 \mathrm{~cm}-\mathrm{T}_{19}-\mathrm{C}_{1}$ Hardwood cuttings $+\mathrm{G} 7$ Rootex) was recorded at 30, 60 and 90 days after planting, respectively.

The minimum length of shoot $\left(2.15 \mathrm{~cm}-\mathrm{T}_{3}-\mathrm{C}_{3}\right.$ Shoot-tip cutting $+\mathrm{G}_{1}$ IBA $2,000 \mathrm{ppm}$, $3.85 \mathrm{~cm}-\mathrm{T}_{10}-\mathrm{C}_{1}$ Hardwood cuttings $+\mathrm{G}_{4}$ IBA $2,000+$ PHB $750 \mathrm{ppm}$ and $4.95 \mathrm{~cm}-\mathrm{T}_{10}-\mathrm{C}_{1}$ Hardwood cuttings $+\mathrm{G}_{4}$ IBA 2,000 + PHB $750 \mathrm{ppm}$ ) at 30, 60 and 90 days after planting, respectively (Table.3).The length of shoots had got increased due to development of primary roots at 60 and 90 DAP as compared to 30 days which enhanced better uptake of nutrients like nitrogen from media for vegetative growth. These results were in accordance with that of Tripathi and Shukla (2004) in pomegranate and Ahmad et al., (2016) in dragon fruit.

\section{Effect on fresh weight}

In the present study growth regulators and type of cuttings and their combinations exhibited significant effect on average fresh weight of cuttings. The maximum fresh weight of cuttings was recorded in hardwood cuttings (17.90g) and rootex (19.69g) as compared to other types of cuttings and PGR's at 30, 60 and 90 days after planting, respectively (Table 2). Hardwood cuttings were produced more fresh weight as compared to other types of cutting as the diameter was more in case of hardwood cuttings.

In the interaction, the highest fresh weight at 90 DAP was recorded in the treatment $T_{19}\left(C_{1}\right.$ Hardwood cuttings + G7 Rootex) with $21.47 \mathrm{~g}$, which was on par with $\mathrm{T}_{7}\left(\mathrm{C}_{1}\right.$ Hardwood cuttings $+\mathrm{G}_{3}$ IBA 4,000 ppm) with $20.70 \mathrm{~g}$ whereas, the lowest fresh weight was recorded in $\mathrm{T}_{15}\left(\mathrm{C}_{3}\right.$ Shoot-tip cutting $+\mathrm{G}_{5}$ IBA 3,000+ PHB 750 ppm) with 13.42g (Table 4). These results were in accordance with that of Mehta et al., (2018) in pomegranate, Filho et al., (2009) in citrumello and Ahmad et al., (2016) in dragon fruit.

\section{Effect on dry weight}

In the present study growth regulators and type of cuttings and their combinations exhibited significant effect on average dry weight of cuttings. The maximum dry weight of cuttings was recorded in hardwood cuttings $(11.83 \mathrm{~g})$ and rootex $(11.34 \mathrm{~g})$ as compared to other types of cuttings and PGR's at 30, 60 and 90 days after planting, respectively (Table 2 ). In the interaction, highest average dry weight had been recorded in the hardwood as the diameter of cuttings were more. 
Table.1 Effect of types of cuttings and PGRs on shoot parameters in jamun

\begin{tabular}{|c|c|c|c|c|c|c|c|c|}
\hline \multirow[t]{2}{*}{ Factor } & \multirow{2}{*}{$\begin{array}{c}\text { Days } \\
\text { taken for } \\
\text { sprout } \\
\text { initiation }\end{array}$} & \multirow{2}{*}{$\begin{array}{l}\text { Percentage } \\
\text { of sprouted } \\
\text { cuttings }\end{array}$} & \multicolumn{3}{|c|}{$\begin{array}{c}\text { Number of sprouts per } \\
\text { cutting }\end{array}$} & \multicolumn{3}{|c|}{$\begin{array}{c}\text { Number of leaves per } \\
\text { cutting }\end{array}$} \\
\hline & & & $\begin{array}{l}\text { 30 } \\
\text { DAP }\end{array}$ & $\begin{array}{l}\text { 60 } \\
\text { DAP }\end{array}$ & $\begin{array}{l}\text { 90 } \\
\text { DAP }\end{array}$ & $\begin{array}{l}\text { 30 } \\
\text { DAP }\end{array}$ & $\begin{array}{l}\text { 60 } \\
\text { DAP }\end{array}$ & $\begin{array}{l}\text { 90 } \\
\text { DAP }\end{array}$ \\
\hline $\mathrm{C}_{1}$ & 14.29 & 12.68 & 9.79 & 8.29 & 5.11 & 4.76 & 6.73 & 7.72 \\
\hline $\mathrm{C}_{2}$ & 12.91 & 5.84 & 8.05 & 7.04 & 4.98 & 4.31 & 6.07 & 6.96 \\
\hline $\mathrm{C}_{3}$ & 11.46 & 4.86 & 6.85 & 6.32 & 4.75 & 4.08 & 5.52 & 6.46 \\
\hline SEm \pm (Cutting) & 0.17 & 0.20 & 0.11 & 0.10 & 0.09 & 0.06 & 0.08 & 0.17 \\
\hline CD (0.05) (Cutting) & 0.51 & 0.57 & 0.33 & 0.29 & 0.25 & 0.18 & 0.25 & 0.49 \\
\hline $\mathbf{G}_{1}$ & 13.63 & 3.86 & 7.83 & 6.82 & 4.65 & 4.09 & 6.18 & 7.15 \\
\hline $\mathbf{G}_{2}$ & 13.52 & 4.23 & 8.34 & 7.32 & 5.00 & 4.08 & 5.28 & 6.28 \\
\hline $\mathbf{G}_{\mathbf{3}}$ & 11.68 & 10.31 & 8.52 & 7.52 & 5.34 & 4.98 & 6.99 & 7.82 \\
\hline $\mathbf{G}_{4}$ & 14.00 & 5.10 & 7.56 & 6.50 & 4.30 & 3.92 & 5.04 & 6.07 \\
\hline $\mathbf{G}_{5}$ & 14.27 & 5.02 & 7.48 & 6.48 & 4.17 & 3.55 & 5.23 & 6.26 \\
\hline $\mathbf{G}_{\mathbf{6}}$ & 11.90 & 9.84 & 8.41 & 7.40 & 5.27 & 4.77 & 6.56 & 7.56 \\
\hline $\mathbf{G}_{7}$ & 11.20 & 16.19 & 9.49 & 8.49 & 5.90 & 5.29 & 7.46 & 8.19 \\
\hline SEm $\pm($ PGR $)$ & 0.27 & 0.30 & 0.17 & 0.15 & 0.13 & 0.09 & 0.13 & 0.25 \\
\hline CD (0.05) (PGR) & 0.78 & 0.88 & 0.50 & 0.44 & 0.38 & 0.28 & 0.37 & 0.75 \\
\hline
\end{tabular}

*Significant at 5 percent level; $\mathrm{C}_{1}$ Hardwood cuttings, $\mathrm{C}_{2}$ Semi-hardwood cutting, $\mathrm{C}_{3}$ Shot-tip cutting, $\mathrm{G}_{1}$ IBA 2,000

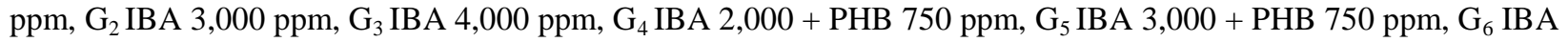
$4,000+$ PHB 750 ppm and $\mathrm{G}_{7}$ Rootex

Table.2 Effect of types of cuttings and PGRs on shoot and root parameters in jamun

\begin{tabular}{|c|c|c|c|c|c|c|c|c|}
\hline \multirow[t]{2}{*}{ Factor } & \multicolumn{3}{|c|}{ Shoot length $(\mathrm{cm})$} & \multirow{2}{*}{$\begin{array}{l}\text { Fresh } \\
\text { weight } \\
\text { (g) }\end{array}$} & \multirow{2}{*}{$\begin{array}{l}\text { Dry } \\
\text { weight } \\
\text { (g) }\end{array}$} & \multirow{2}{*}{$\begin{array}{l}\text { Number of } \\
\text { primary and } \\
\text { secondary } \\
\text { roots }\end{array}$} & \multirow{2}{*}{$\begin{array}{l}\text { Longest } \\
\text { root length } \\
\text { (cm) }\end{array}$} & \multirow{2}{*}{$\begin{array}{l}\text { Percentage } \\
\text { of rooted } \\
\text { cuttings }\end{array}$} \\
\hline & $\begin{array}{c}30 \\
\text { DAP }\end{array}$ & $\begin{array}{c}60 \\
\text { DAP }\end{array}$ & $\begin{array}{c}90 \\
\text { DAP }\end{array}$ & & & & & \\
\hline $\mathrm{C}_{1}$ & 4.66 & 5.93 & 6.75 & 17.90 & 11.83 & 50.18 & 15.55 & 27.71 \\
\hline $\mathrm{C}_{2}$ & 4.37 & 5.53 & 5.85 & 16.58 & 9.60 & 48.81 & 12.66 & 14.01 \\
\hline $\mathbf{C}_{3}$ & 4.10 & 5.31 & 6.54 & 15.64 & 7.86 & 45.69 & 9.01 & 9.39 \\
\hline SEm $\pm($ Cutting $)$ & 0.08 & 0.09 & 0.14 & 0.23 & 0.15 & 0.74 & 0.17 & 0.42 \\
\hline CD (0.05) (Cutting) & 0.23 & 0.25 & 0.42 & 0.67 & 0.43 & 2.18 & 0.49 & 1.24 \\
\hline $\mathbf{G}_{1}$ & 2.93 & 4.36 & 5.35 & 15.12 & 9.25 & 39.38 & 10.65 & 15.88 \\
\hline $\mathbf{G}_{\mathbf{2}}$ & 3.41 & 4.65 & 5.58 & 16.41 & 9.45 & 48.51 & 11.79 & 16.50 \\
\hline $\mathbf{G}_{\mathbf{3}}$ & 5.97 & 7.33 & 7.79 & 18.55 & 10.51 & 52.92 & 13.81 & 18.62 \\
\hline $\mathbf{G}_{4}$ & 3.00 & 4.07 & 5.05 & 14.39 & 8.60 & 42.78 & 11.64 & 14.50 \\
\hline $\mathbf{G}_{5}$ & 3.40 & 4.33 & 5.43 & 15.23 & 9.00 & 46.00 & 11.70 & 15.43 \\
\hline $\mathbf{G}_{6}$ & 5.65 & 6.79 & 7.52 & 17.56 & 10.18 & 52.65 & 12.99 & 17.45 \\
\hline $\mathbf{G}_{7}$ & 6.25 & 7.62 & 7.93 & 19.69 & 11.34 & 55.35 & 14.28 & 20.90 \\
\hline SEm $\pm($ PGR $)$ & 0.12 & 0.13 & 0.22 & 0.35 & 0.22 & 1.13 & 0.25 & 0.64 \\
\hline CD (0.05) (PGR) & 0.35 & 0.38 & 0.64 & 1.02 & 0.66 & 3.33 & 0.75 & 1.89 \\
\hline
\end{tabular}

*Significant at 5 percent level 
Table.3 Effect of Interaction of type of cutting and PGRs on shoot parameters in jamun

\begin{tabular}{|c|c|c|c|c|c|c|c|c|c|c|c|c|}
\hline \multirow[t]{2}{*}{$\begin{array}{c}\text { S. } \\
\text { No. }\end{array}$} & \multirow[t]{2}{*}{$\begin{array}{l}\text { Treatment } \\
\text { details }\end{array}$} & \multirow{2}{*}{$\begin{array}{l}\text { Days taken } \\
\text { for sprout } \\
\text { initiation }\end{array}$} & \multirow{2}{*}{$\begin{array}{c}\text { Percentage } \\
\text { of } \\
\text { Sprouted } \\
\text { cuttings }\end{array}$} & \multicolumn{3}{|c|}{$\begin{array}{c}\text { Number of Sprouts per } \\
\text { cutting }\end{array}$} & \multicolumn{3}{|c|}{$\begin{array}{l}\text { Number of leaves per } \\
\text { cutting }\end{array}$} & \multicolumn{3}{|c|}{ Shoot length $(\mathrm{cm})$} \\
\hline & & & & 30 DAP & 60 DAP & 90 DAP & $\begin{array}{c}\text { 30 } \\
\text { DAP }\end{array}$ & $\begin{array}{l}\text { 60 } \\
\text { DAP }\end{array}$ & $\begin{array}{c}90 \\
\text { DAP }\end{array}$ & $\begin{array}{c}30 \\
\text { DAP }\end{array}$ & $\begin{array}{c}\text { 60 } \\
\text { DAP }\end{array}$ & $\begin{array}{c}90 \\
\text { DAP }\end{array}$ \\
\hline 1 & $\mathrm{~T}_{1-} \mathrm{C}_{1} \mathrm{G}_{1}$ & 15.50 & 4.20 & 9.35 & 7.85 & 4.85 & 4.54 & 6.03 & 7.18 & 3.45 & 4.30 & 5.10 \\
\hline 2 & $\mathrm{~T}_{2-} \mathrm{C}_{2} \mathrm{G}_{1}$ & 13.00 & 4.15 & 7.66 & 6.66 & 4.65 & 3.72 & 5.29 & 6.06 & 3.20 & 4.70 & 5.75 \\
\hline 3 & $\mathrm{~T}_{3-} \mathrm{C}_{3} \mathrm{G}_{1}$ & 12.40 & 3.22 & 6.50 & 5.96 & 4.45 & 4.03 & 7.23 & 8.23 & 2.15 & 4.08 & 5.20 \\
\hline 4 & $\mathrm{~T}_{4-} \mathrm{C}_{1} \mathrm{G}_{2}$ & 14.00 & 4.65 & 9.45 & 7.95 & 5.20 & 4.38 & 6.29 & 7.33 & 4.00 & 5.30 & 6.20 \\
\hline 5 & $\mathrm{~T}_{5-} \mathrm{C}_{2} \mathrm{G}_{2}$ & 13.75 & 4.50 & 8.00 & 7.00 & 5.00 & 4.03 & 5.30 & 6.25 & 3.29 & 4.40 & 5.25 \\
\hline 6 & $\mathrm{~T}_{6-} \mathrm{C}_{3} \mathrm{G}_{2}$ & 12.80 & 3.55 & 7.56 & 7.01 & 4.80 & 3.84 & 4.26 & 5.26 & 2.95 & 4.24 & 5.29 \\
\hline 7 & $\mathrm{~T}_{7-} \mathrm{C}_{1} \mathrm{G}_{3}$ & 13.50 & 16.00 & 9.75 & 8.25 & 5.20 & 5.00 & 7.30 & 7.88 & 6.10 & 7.90 & 8.43 \\
\hline 8 & $\mathrm{~T}_{8-} \mathrm{C}_{2} \mathrm{G}_{3}$ & 12.03 & 7.95 & 8.50 & 7.50 & 5.50 & 5.28 & 7.34 & 8.34 & 6.15 & 7.25 & 6.65 \\
\hline 9 & $\mathrm{~T}_{9-} \mathrm{C}_{3} \mathrm{G}_{3}$ & 9.50 & 6.98 & 7.31 & 6.81 & 5.31 & 4.67 & 6.33 & 7.24 & 5.67 & 6.84 & 8.30 \\
\hline 10 & $\mathrm{~T}_{10-} \mathrm{C}_{1} \mathrm{G}_{4}$ & 15.00 & 9.70 & 9.04 & 7.51 & 4.50 & 4.43 & 5.89 & 7.00 & 2.90 & 3.85 & 4.95 \\
\hline 11 & $\mathrm{~T}_{11-} \mathrm{C}_{2} \mathrm{G}_{4}$ & 13.65 & 3.30 & 7.40 & 6.30 & 4.30 & 3.80 & 5.10 & 6.10 & 3.00 & 4.35 & 5.09 \\
\hline 12 & $\mathrm{~T}_{12-} \mathrm{C}_{3} \mathrm{G}_{4}$ & 13.35 & 2.31 & 6.23 & 5.70 & 4.10 & 3.54 & 4.12 & 5.12 & 3.10 & 4.01 & 5.12 \\
\hline 13 & $\mathrm{~T}_{13-} \mathrm{C}_{1} \mathrm{G}_{5}$ & 15.00 & 9.25 & 8.91 & 7.41 & 4.40 & 4.33 & 6.26 & 7.32 & 3.75 & 4.50 & 5.55 \\
\hline 14 & $\mathrm{~T}_{14-} \mathrm{C}_{2} \mathrm{G}_{5}$ & 14.00 & 3.40 & 7.61 & 6.61 & 4.20 & 3.28 & 5.19 & 6.18 & 3.15 & 4.25 & 5.00 \\
\hline 15 & $\mathrm{~T}_{15-} \mathrm{C}_{3} \mathrm{G}_{5}$ & 13.80 & 2.40 & 5.91 & 5.41 & 3.90 & 3.05 & 4.26 & 5.30 & 3.30 & 4.23 & 5.75 \\
\hline 16 & $\mathrm{~T}_{16-} \mathrm{C}_{1} \mathrm{G}_{6}$ & 14.00 & 15.05 & 10.01 & 8.51 & 5.50 & 4.95 & 7.18 & 8.18 & 6.10 & 7.55 & 8.39 \\
\hline 17 & $\mathrm{~T}_{17-} \mathrm{C}_{2} \mathrm{G}_{6}$ & 12.00 & 7.70 & 8.31 & 7.31 & 5.30 & 4.80 & 6.66 & 7.66 & 5.35 & 6.29 & 6.45 \\
\hline 18 & $\mathrm{~T}_{18-} \mathrm{C}_{3} \mathrm{G}_{6}$ & 9.70 & 6.77 & 6.92 & 6.37 & 5.00 & 4.55 & 5.84 & 6.84 & 5.51 & 6.54 & 7.72 \\
\hline 19 & $\mathrm{~T}_{19-} \mathrm{C}_{1} \mathrm{G}_{7}$ & 13.00 & 29.90 & 12.05 & 10.55 & 6.10 & 5.68 & 8.15 & 9.15 & 6.30 & 8.15 & 8.64 \\
\hline 20 & $\mathrm{~T}_{20-} \mathrm{C}_{2} \mathrm{G}_{7}$ & 11.95 & 9.85 & 8.90 & 7.90 & 5.90 & 5.29 & 7.65 & 8.16 & 6.45 & 7.45 & 6.74 \\
\hline 21 & $\mathrm{~T}_{21}-\mathrm{C}_{3} \mathrm{G}_{7}$ & 8.65 & 8.83 & 7.53 & 7.01 & 5.70 & 4.90 & 6.59 & 7.28 & 6.00 & 7.25 & 8.41 \\
\hline \multicolumn{2}{|c|}{ SEm \pm} & 0.46 & 0.29 & 0.21 & 0.17 & 0.23 & 0.16 & 0.22 & 0.44 & 0.21 & 0.23 & 0.38 \\
\hline \multicolumn{2}{|c|}{ CD (0.05) } & $1.36 *$ & $0.87 *$ & $0.62 *$ & $0.50 *$ & $0.66^{*}$ & $0.48^{*}$ & $0.65^{*}$ & $1.29 *$ & $0.60 *$ & $0.67 *$ & $1.11^{*}$ \\
\hline
\end{tabular}

*Significant at 5 percent level; $\mathrm{C}_{1}$-Hardwood cuttings, $\mathrm{C}_{2}$ - Semi hardwood cuttings, C- Shoot-tip cuttings, $\mathrm{G}_{1}-2000 \mathrm{ppm}$ IBA, G2- 3000ppm IBA, G 3 - 4000ppm IBA, $\mathrm{G}_{4}$ - IBA 2,000 + PHB 750 ppm, $\mathrm{G}_{5-}$ IBA 3,000 + PHB 750 ppm, $\mathrm{G}_{6-}$ 4,000 + PHB 750 ppm and $\mathrm{G}_{7-}$ Rootex 
Table.4 Effect of Interaction of type of cutting and PGRs on root parameters in jamun

\begin{tabular}{|c|c|c|c|c|c|c|}
\hline S. No. & $\begin{array}{l}\text { Treatment } \\
\text { Details }\end{array}$ & $\begin{array}{l}\text { Fresh } \\
\text { weight } \\
\text { (gram) }\end{array}$ & $\begin{array}{l}\text { Dry weight } \\
\text { (gram) }\end{array}$ & $\begin{array}{c}\text { Number of } \\
\text { primary and } \\
\text { secondary roots }\end{array}$ & $\begin{array}{l}\text { Length of } \\
\text { longest root } \\
\text { (cm) }\end{array}$ & $\begin{array}{c}\text { Percentage } \\
\text { of rooted } \\
\text { cuttings }\end{array}$ \\
\hline 1 & $\mathrm{~T}_{1-} \mathrm{C}_{1} \mathrm{G}_{1}$ & 15.50 & 10.30 & 42.15 & 13.05 & 26.85 \\
\hline 2 & $\mathrm{~T}_{2-} \mathrm{C}_{2} \mathrm{G}_{1}$ & 14.63 & 9.85 & 39.75 & 11.14 & 12.15 \\
\hline 3 & $\mathrm{~T}_{3-} \mathrm{C}_{3} \mathrm{G}_{1}$ & 15.24 & 7.60 & 36.25 & 7.76 & 8.65 \\
\hline 4 & $\mathrm{~T}_{4-} \mathrm{C}_{1} \mathrm{G}_{2}$ & 18.17 & 12.11 & 42.93 & 15.05 & 26.60 \\
\hline 5 & $\mathrm{~T}_{5-} \mathrm{C}_{2} \mathrm{G}_{2}$ & 16.68 & 9.06 & 52.99 & 12.04 & 13.95 \\
\hline 6 & $\mathrm{~T}_{6-} \mathrm{C}_{3} \mathrm{G}_{2}$ & 14.40 & 7.20 & 49.60 & 8.27 & 8.95 \\
\hline 7 & $\mathrm{~T}_{7-} \mathrm{C}_{1} \mathrm{G}_{3}$ & 20.70 & 12.36 & 56.88 & 16.22 & 30.70 \\
\hline 8 & $\mathrm{~T}_{8-} \mathrm{C}_{2} \mathrm{G}_{3}$ & 17.42 & 10.33 & 52.20 & 14.24 & 14.10 \\
\hline 9 & $\mathrm{~T}_{9-} \mathrm{C}_{3} \mathrm{G}_{3}$ & 17.53 & 8.85 & 49.68 & 10.98 & 11.05 \\
\hline 10 & $\mathrm{~T}_{10-} \mathrm{C}_{1} \mathrm{G}_{4}$ & 15.28 & 10.48 & 45.60 & 15.40 & 20.95 \\
\hline 11 & $\mathrm{~T}_{11-} \mathrm{C}_{2} \mathrm{G}_{4}$ & 14.16 & 8.23 & 42.70 & 12.37 & 13.95 \\
\hline 12 & $\mathrm{~T}_{12-} \mathrm{C}_{3} \mathrm{G}_{4}$ & 13.73 & 7.09 & 40.04 & 7.16 & 8.60 \\
\hline 13 & $\mathrm{~T}_{13-} \mathrm{C}_{1} \mathrm{G}_{5}$ & 15.67 & 11.14 & 49.46 & 15.74 & 24.35 \\
\hline 14 & $\mathrm{~T}_{14-} \mathrm{C}_{2} \mathrm{G}_{5}$ & 16.60 & 9.15 & 46.00 & 11.14 & 13.90 \\
\hline 15 & $\mathrm{~T}_{15-} \mathrm{C}_{3} \mathrm{G}_{5}$ & 13.42 & 6.71 & 42.55 & 8.23 & 8.05 \\
\hline 16 & $\mathrm{~T}_{16-} \mathrm{C}_{1} \mathrm{G}_{6}$ & 18.52 & 12.15 & 56.65 & 16.56 & 29.15 \\
\hline 17 & $\mathrm{~T}_{17-} \mathrm{C}_{2} \mathrm{G}_{6}$ & 17.07 & 9.75 & 52.60 & 13.04 & 14.20 \\
\hline 18 & $\mathrm{~T}_{18-} \mathrm{C}_{3} \mathrm{G}_{6}$ & 17.10 & 8.65 & 48.70 & 9.39 & 9.00 \\
\hline 19 & $\mathrm{~T}_{19-} \mathrm{C}_{1} \mathrm{G}_{7}$ & 21.47 & 14.25 & 57.60 & 16.85 & 35.40 \\
\hline 20 & $\mathrm{~T}_{20-} \mathrm{C}_{2} \mathrm{G}_{7}$ & 19.50 & 10.83 & 55.45 & 14.69 & 15.85 \\
\hline 21 & $\mathrm{~T}_{21-} \mathrm{C}_{3} \mathrm{G}_{7}$ & 18.10 & 8.93 & 52.99 & 11.29 & 11.45 \\
\hline \multicolumn{2}{|c|}{$\mathrm{SEm} \pm$} & 0.66 & 0.39 & 1.96 & 0.44 & 1.12 \\
\hline \multicolumn{2}{|c|}{ CD $(0.05)$} & $1.77 *$ & $1.14 *$ & $5.76 *$ & $1.30 *$ & $3.28 *$ \\
\hline
\end{tabular}

*Significant at 5 percent level

The highest dry weight at 90 DAP was recorded in the treatment $\mathrm{T}_{19}\left(\mathrm{C}_{1}\right.$ Hardwood cuttings $+\mathrm{G} 7$ Rootex) with $14.25 \mathrm{~g}$, followed by $\mathrm{T}_{7}\left(\mathrm{C}_{1}\right.$ Hardwood cuttings $+\mathrm{G}_{3}$ IBA 4,000 ppm) with $12.36 \mathrm{~g}$ whereas, the lowest fresh weight was recorded in $T_{15}\left(C_{3}\right.$ Shoot-tip cutting $+\mathrm{G}_{5}$ IBA 3,000 + PHB $750 \mathrm{ppm}$ ) with $6.71 \mathrm{~g}$ (Table 4).

These results were in accordance with that of Gurjar and Patel (2006) in pomegranate, Sardoei (2014) in guava and Ahmad et al., (2016) in dragon fruit.
Effect on number of primary and secondary root

In the present study growth regulators and type of cuttings and their combinations exhibited significant effect on average number of primary and secondary roots. Number of primary and secondary roots was more in the hardwood cuttings (50.18) and rootex (55.35) treated cuttings compared to others (Table 2). In the interaction, the highest number of primary and secondary roots per cutting had been recorded in $\mathrm{T}_{19} \quad\left(\mathrm{C}_{1}\right.$ Hardwood cuttings + G7 Rootex) with 57.60, which is on par with $\mathrm{T}_{7} \quad\left(\mathrm{C}_{1}\right.$ Hardwood 
cuttings $+\mathrm{G}_{3}$ IBA $4,000 \mathrm{ppm}$ ) with 56.88 whereas, the lowest number of roots was observed in the treatment $T_{3}\left(C_{3}\right.$ Shoot-tip cutting+ $\mathrm{G}_{1}$ IBA 2,000 ppm) of about 36.25 roots (Table 4).

Number of primary and secondary roots was more in the hardwood cuttings as the dry matter of cuttings were more. These results were in accordance with that of Bastos et al., (2006) in litchi, Akakpo et al., (2014) in sheanut tree and Singh et al., (2013) in pant lemon.

\section{Effect on length of longest root}

In the present study growth regulators and type of cuttings and their combinations exhibited significant effect on length of longest root (Table 2). Overall, the longest length of primary root was recorded in the hardwood cutting and rootex treated plants.

It might be due to an auxin application has been found to enhance the histological features like formation of callus, tissue and differentiation of vascular tissue and also due to the assimilation and translocation of auxins compound in rooted cutting. In the interaction, Length of longest root was more in the hardwood cuttings $(15.55 \mathrm{~cm})$ and rootex $(14.28 \mathrm{~cm})$ treated cuttings compared to others (Table 4). The highest length of longest root per cutting was recorded in $\mathrm{T}_{19}\left(\mathrm{C}_{1}\right.$ Hardwood cuttings + G7 Rootex) with $16.85 \mathrm{~cm}$ whereas, the lowest length of primary roots was observed in the treatment $\mathrm{T}_{12}\left(\mathrm{C}_{3}\right.$ Shoot-tip cutting $+\mathrm{G}_{4}$ IBA $2,000+$ PHB $750 \mathrm{ppm}$ ) with $7.16 \mathrm{~cm}$ (Table 4). These results were in accordance with that of Galavi et al., (2013) in Grape, Akakpo et al., (2014) in sheanut tree, Mehta et al., (2018) in pomegranate and Singh et al., (2019) pant lemon.

\section{Percentage of rooted cuttings}

In the present study growth regulators and type of cuttings and their combinations exhibited significant effect on percentage of rooted cuttings cuttings. Percentage of rooted cuttings was more in the hardwood cuttings (27.71) and rootex (20.90) treated cuttings compared to others (Table 2). Overall, highest percentage of rooting was recorded in the hardwood cuttings compared to other type of cuttings and rootex was best growth regulator to record highest rooting compared to other conditions.

It might be due to the rapid hydrolysis of polysaccharides stored in stem cuttings into physiologically active sugars which provide energy to meristematic tissues and activate the root primodia to initiate formation of more number of roots in stem cuttings. In the interaction, the highest rooting percentage was recorded in treatment $\mathrm{T}_{19}\left(\mathrm{C}_{1}\right.$ Hardwood cuttings + G7 Rootex) with 35.40 per cent whereas, the lowest rooting percentage was observed in treatment $\mathrm{T}_{15} \quad\left(\mathrm{C}_{3}\right.$ Shoot-tip cutting $+\mathrm{G}_{5}$ IBA 3,000 + PHB $750 \mathrm{ppm}$ ) with 8.05 per cent (Table 4 ).

These results were in accordance with that of Filho et al., (2009) in citrumello, Karimi et al., (2012) in Pomegranate, Akakpo et al., (2014) in sheanut tree and Mehta et al., (2018) in pomegranate.

The hardwood cutting in combination with rootex was superior to show more shooting and rooting parameters in jamun. The results would be very useful in standardization of an efficient protocol for multiplication of jamun through cuttings.

\section{References}

Ahmad, H., Mirana, S. A., Mahbuba, S., Tareq, S. M. and Uddin, 2016, Performance of IBA concentrations for rooting of dragon fruit (Hylocereus undatus) stem cuttings. International J. Business, Social and Scientific Res., 4: 231-234. 
Akakpo, D., Amissah, N., Yeboah, J. and Blay, E., 2014, Effect of Indole 3-Butyric Acid and media type on adventitious root formation in Sheanut tree (Vitellaria paradoxa C. F. Gaertn.) stem cuttings. American J. Plant Sci., 5(3): 313-318.

Ayesha, S. and Thippesha, D., 2018, Influence of plant growth regulators on rooting of stem cuttings in dragon fruit [Hylocereus undatus (Haworth) Britton \& Rose], International journal of chemical studies,6(5): 1834-1839.

Bastos, D. C., Pio, R., Scarparefilho, J.A. and Almeida, L.E.P., 2006, Type of cuttings and concentration of lndole butyric acid on the lychee tree propagation. Ciencia-eAgrotechnologia, 30(1): 97-102.

Bhattacharjee, S. K. and Thimmappa, D.K. 1993, Effect of number of days on rooting of cuttings of Pelargonium graveolens Herit and Pogostemon patchouli Benth. IndianPerfumer., 36(3): 178-181.

Cleland, R. 1973, Auxin induced hydrogen in excretion from Avena coleoptile. Proc. Nat. Acad. Sci., 7: 3092-3093.

Filho, F. D. A. A. M., Girardi, E. A. and Couto, H. T. Z. D., 2009, 'Swingle' citrumelo propagation by cuttings for citrus nursery tree production. Scientia Hort., 120: 207212.

Gurjar, P.K.S. and Patel, R. M., 2006, Effect of rooting media, type of stem cutting and growth regulator on rooting and growth of pomegranate cv. Ganesh. JNKVV, Res. J., 40(1-2): 122-124.

Hussain, I., Nabi, G., Rehman, H., Shah, K. and Ali, S., 2016, Effect of different environmental condition on different types of sweet lime cuttings. Pure Appl. Bio., 3(1): 18-21.
Kumar, S., Shukla, H.S. and Kumar, S., 2004, Effect of IBA and PHB on the regeneration of sweet lime through stem cuttings.

Mehta, S. K., Singh, K.K. and Harsana, A. S., 2018, Effect of IBA concentration and time of planting on rooting in pomegranate (Punica granatum) cuttings. J. Medicinal Plants Studies, 6(1): 250253.

Roberts, E. H. 1983, Seeds (Ed. J.R. Thompson). In Adv. Res. Technol., 8: 934.

Sardoei, A. S., 2014, Effect of different media of cuttings on rooting of guava (Psidium guajava L.). European J. Experimental Bio., 2014, 4(2):88-92.

Siddiqui, M. I. and Hussain, S. A., 2009, Effect of indole butyric acid and types of cuttings on root initiation of Ficus Hawaii. Sarhad J. Agri., 23(4): 919-925.

Singh, K. K., Choudhary, T. and Kumar, P., 2013, Effect of IBA on growth and rooting of Citrus limon cv. Pant lemon cuttings. Hortflora Research Spectrum, 2(3): 2250-2823.

Singh, K. K. and Chouhan, J. S., 2016, The effect of different times collecting cutting, growing conditions and auxin treatments of the rooting in phalsa (Grewia asiatica L.) stem cutting under vally condition of Garahwl.Plant Archives, 16(2):781-788.

Triptahi, S. N. and Shukla, H. S., 2004, Propagation of pomegranate cultivars by stem cuttings with Indole-butyric acid and Phydroxybenzolc acid, Indian J. Hort., 61(4): 362-365.

\section{How to cite this article:}

Bhairavi B. M., D. P. Prakasha, H. Kulapathi, N. Anand, G. R. Sanjeev Raddi and Gollagi, S. G. 2019. Influence of Plant Growth Regulators on Rooting of Stem Cuttings in Jamun (Syzygium cumini L. Skeels). Int.J.Curr.Microbiol.App.Sci. 8(09): 2997-3006. doi: https://doi.org/10.20546/ijcmas.2019.809.343 